\title{
Research on Teaching Reform of University Audit Against the Background of Internet Plus
}

\author{
Liyun Chen ${ }^{1, *}$ \\ ${ }^{1}$ School of Economics and Management, Zaozhuang University, Zaozhuang, Shandong, China \\ *Corresponding author. Email: 1552945680@qq.com
}

\begin{abstract}
Under the background of "Internet + ", audit teaching mainly has two problems. First, the audit teaching faculty to adapt to the changes of "Internet Plus" is relatively weak. Second, the audit teaching material system is relatively old. In order to promote the reform of audit teaching, colleges and universities should change the mode of audit teaching, combine offline teaching with online teaching, promote the integration of audit teaching and accounting teaching, and establish information-based audit training base according to the conditions.
\end{abstract}

Keywords: Internet plus, Auditing, Teaching reform.

\section{INTRODUCTION}

Audit is an independent economic supervision activity in which professionals use specific technology, adopt standardized process, and review the legality and fairness of economic projects and financial revenues and expenditures of government agencies, enterprises and institutions at all levels before and after the event in accordance with the requirements of laws or regulations. The supervision subject of audit behavior is the accounting activities of government agencies, enterprises and institutions at all levels. Its main form is to review the accounting reports, accounting books, accounting vouchers and other accounting data of the audited units, so as to find out the possible errors and fraud, and make corresponding treatment according to the audit regulations. It can be said that the basis of audit is accounting, and accounting reform will inevitably lead to corresponding changes in audit work. Nowadays, the rapid development of Internet technology has brought great influence on accounting practice and accounting theory, and it is inevitable that the audit work as a superstructure will require corresponding adjustments. Accordingly, in order to cultivate audit talents in line with the characteristics of the times, the audit teaching in colleges and universities should also adapt to the development of network technology and change the teaching mode. The vigorous development of "Internet Plus" technology has brought a great impulse to the accounting work in China. New forms of business and trading modes keep spring up, and accounting theories and practices are constantly innovating, which will inevitably affect the auditing practice and thus further influence the auditing teaching work in colleges and universities. In order to adapt to the new situation and cultivate audit talents who can adapt to modern "Internet Plus" technology, the audit work in universities must be reformed.

\section{PROBLEMS OF TEACHING AUDIT IN UNIVERSITIES UNDER THE BACKGROUND OF "INTERNET PLUS"}

At the time being, the audit teaching faculty to adapt to the changes of "Internet Plus" is relatively weak. The main sources of audit teachers in various financial institutions and comprehensive institutions in China are postgraduates and doctoral students of accounting or audit related majors. Generally, these personnel, lacking enterprise experience, directly enter colleges and universities to teach after graduation. Their advantages lie in long-term systematic training, rich professional theoretical knowledge and strong teaching ability, but audit is a work that comes with high practical requirements, which requires practitioners to have a more detailed understanding of enterprise accounting practice and accounting development 
trend. Students who only have the theoretical knowledge of accounting and audit usually cannot deal with the actual audit business.

The rapid development of "Internet Plus" technology has brought about tremendous influence on the practice of financial accounting. Accounting work is becoming more complex and changeable with more and more new forms of organization and transaction emerging, which requires more flexible auditing teaching. Audit teachers should be able to design more teaching cases in the context of "Internet Plus", and have the ability to guide students to analyze these cases in detail, which placed higher demands on audit teaching staff. But at present, most of our audit teachers are limited in colleges and universities for a long time, it is difficult to have the opportunity to systematically participate in the enterprise accounting practice, resulting in teachers' own outdated knowledge system, lack of advanced financial work experience in enterprises, and their own inability to master cutting-edge accounting knowledge. Most of the audit teaching in China's finance and economics majors mainly adopt the traditional teacher-oriented and theoretical lectures as the main form of classroom teaching mode, which is one-sided and backward with the reform of accounting work. This kind of old learning mode and content is difficult to mobilize students' enthusiasm for learning, and it is very challenging for students to apply the knowledge learned in the classroom to the practice after graduation into society.

The audit teaching material system is relatively old. At present, the audit course offered by financial colleges in China is mainly the audit of certified public accountants, the audit object is the annual financial statements of enterprises. The audit teaching materials published by various publishing houses are all similar, generally including audit theory and audit practice. The audit theory mainly introduces the concepts of audit object, audit procedure, audit standard, audit plan, audit risk and so on. The practical part is divided into sales and collection cycle audit, procurement and payment cycle audit, production and expense cycle audit and so on. Although this kind of teaching material system is very standard, and basically consistent with the content of international audit teaching materials, there are some problems. First, whether it is the audit theory or the audit practice, the overall content of the textbook is too theoretical and abstract, which leads to teachers paying more attention to theoretical teaching than practical business explanation in the classroom teaching process, resulting in students' lack of hands-on ability. Taking production and expense cycle audit as an example, the teaching content includes production and expense cycle test, internal control and its test, inventory cost audit, inventory monitoring and so on. Although it is audit practice, the teaching content is still biased towards theory. The practical exercises are usually given by the lecturer as accounting cases of enterprises, and the students analyze the errors and propose corrections according to their accounting knowledge, but the students do not see the real accounting information during the whole process. Second, there are great differences in accounting practice in different industries. The rapid development of "Internet Plus" technology has brought about a new form of business and trading mode. These enterprises in different industries are quite different in accounting methods, accounting subjects used, types and periods of taxes paid. For example, the real estate industry focuses on cost control, which is greatly affected by the national economic policy; the accounting of the financial industry is relatively simple, but the types of financial innovation are diverse, and the industry risk is high; the accounting of industrial manufacturing enterprises is complex, and there is a greater possibility of errors and disadvantages. The audit work of different industries should be tailored according to the characteristics of the industry, but China still adopts the general audit teaching materials, which does not reflect the characteristics of the industry, which also brings difficulties for students to apply the knowledge learned in the classroom to practical work in the future.

\section{POLICY SUGGESTIONS ON PROMOTING AUDIT TEACHING REFORM}

The online and offline hybrid Flipped Classroom teaching mode is the product of the "Internet Plus" era, which can help teachers update their teaching ideas and make a breakthrough in the teaching mode of auditing. Compared with other financial professional courses, audit course is more obscure and difficult to understand, it is difficult to stimulate students' interest in autonomous learning, unless forced by the pressure of the final exam; in the daily learning process, few students will take the initiative to preview before class and review after class. Moreover, under the support of "Internet Plus" technology, online source of learning resources is becoming more and more abundant. Teaching courses in famous universities, such as 
Tsinghua University, Peking University, Fudan University, Shanghai Jiao Tong University and so on, can be freely acquired on open network platforms. All kinds of students can share the teachings of top scholars at home without leaving home, which means the content taught by teachers in class is often knowledge that students can easily obtain through online resources in class. In that case, even if the teachers' classroom content is brilliantly designed, it is still difficult to mobilize students' interest in learning, which wastes valuable classroom lecture time. However, because online teaching resources are generally video courses, teachers and students can not communicate effectively face to face, so online learning can not replace offline teaching, it can only be used as a useful supplement to offline teaching. On the one hand, it can expand students' knowledge and provide students with more choices. On the other hand, online teaching can break the geographical and time limitation of offline teaching to make full use of students' fragmented time, students can participate in the learning process at any time and place.

Using the online-offline mixed Flipped Classroom teaching mode, the positions of teachers and students are exchanged, the initiative of learning is handed over to students, the role of teachers is changed from the traditional knowledge carrier to the instructor and question-answering person, and the offline classroom is changed from knowledge infusion to guiding students to carry out case analysis and question discussion. In the specific implementation process, teachers can not only make use of the existing network platform resources, but also use MOOC, micro-lectures and other forms to build online teaching platform aiming at the teaching characteristics and students' characteristics. Teachers should share the network addresses of video resources, case resources and PPT resources related to the course with students before class teaching, and require students to watch and preview before offline teaching. Online teaching resources should be as rich and diverse as possible, so that students can choose learning resources with different difficulties according to their learning ability, so as to achieve the specificity and hierarchy of teaching work. Offline teaching time can be used not only to explain new theoretical knowledge, but also to cooperate with online teaching to answer questions, organize students to make on-site reports on case analysis, and require students to complete necessary online-and-offline homework after the teaching. In order to ensure the teaching quality, the mixed teaching mode should be evaluated regularly, students' opinions and suggestions should be collected, and the teaching methods and contents should be adjusted in time to ensure the teaching effect.

Teachers should promote the integration of audit teaching and accounting teaching. The work results of financial accounting, such as financial reports, accounting books and accounting vouchers, are the objects of audit. Audit and accounting work are inseparable in essence. However, in the current teaching system of finance and economics, audit and accounting are not related to each other. There are great differences between them in terms of semester, teaching content and knowledge system, and the correlation is not enough. Generally speaking, for undergraduate students majoring in auditing, they mainly study the basic professional courses such as accounting principles, intermediate financial accounting and financial management in the freshman and sophomore year, and only in the junior year can they set up more complex professional courses such as auditing and advanced financial accounting. The key advantage of this setting is that auditing is a complex discipline, which requires students to have the ability to master a certain basis of accounting knowledge and the formation of a relatively complete knowledge system. The audit opened in a higher grade is conducive to students to understand the more complex audit theory and audit practice knowledge, but the problems are obvious: the audit and accounting learning time, and the learning content are completely separated, which makes it difficult for students to combine accounting knowledge and audit knowledge. They are regarded as two different courses, which increases the learning difficulty and makes it difficult to understand the process setting of audit practice.

In the Internet era, accounting has gone online. Due to the development of computer technology and big data technology, audit activities engaged in supervision gradually develop to in-process supervision, even in large enterprises with more perfect information system can achieve real-time supervision, the relationship between audit and accounting is getting closer every day. Accordingly, audit teaching and accounting teaching can be integrated and combined. Taking Fixed Assets as an example, the traditional accounting teaching focuses on the accounting treatment of economic business related to fixed assets, which is generally divided into the confirmation of fixed assets, the initial measurement of fixed assets, the subsequent 
measurement of fixed assets, and the disposal of fixed assets. The focus of the learning is how to correctly write the corresponding accounting entries. For the audit teaching of fixed assets, the main contents include the procurement process of fixed assets, risk point control, audit procedures of fixed assets and accumulated depreciation, etc. In the use of computerized teaching method, the two can be integrated together. First, explain the risk points in the control procedures of fixed assets, then explain the accounting treatment methods, and finally teach the students about the errors and disadvantages that frequently appear and how to find and correct them.

Universities should establish an information audit training base. There are two ways to establish an information audit training base. First of all, we should make use of the theoretical and talent advantages of colleges and universities to cooperate with accounting firms and leading enterprises in various industries, build audit training bases, organize teachers and students to participate in enterprise audit practice regularly, and contact the most advanced audit technology and audit theory. In practice, we can closely combine audit teaching with audit practice, promote practice through learning, deepen the understanding of learning content through practice, effectively reduce the abstract sense of audit teaching, and enhance students' understanding of audit. For example, take the audit business of the ending value of inventory as an example, suppose the title describes that the book value of the ending inventory of the audited unit is one million yuan, the net realizable value is 800,000 yuan after testing, and the enterprise does not withdraw the inventory falling price reserves. In the traditional teaching, students are to point out the mistakes in the accounting treatment of the enterprise and correct them. If combined with audit practice, students can personally contact with the final inventory process, how the book value is calculated, and how the net realizable value is obtained, so as to form a systematic knowledge system

Second, introduce the audit training software, and establish intelligent teaching platform. Although the students will have much more authentic experiences of they have practical training in the actual enterprises, the practice cost is relatively high and the practice time is limited. Colleges and universities can use their own computerized classrooms to introduce audit training software and establish an information-based training base. Teachers can also record audit practice work videos and upload case analysis to the network platform for students to watch and learn. For students without practical work experience, the audit process and audit skills described in books are too abstract and difficult to understand. After changing them into video presentation, students can imitate and practice after watching, which is conducive to students' understanding of the teaching content.

\section{CONCLUSION}

The basis of audit is accounting. Accounting reform will inevitably lead to corresponding changes in audit work. Nowadays, the rapid development of Internet technology has brought a great impact on accounting practice and accounting theory, which is bound to require the audit work as the superstructure to make corresponding adjustments. Accordingly, the audit teaching in colleges and universities should also adapt to the development of network technology. In order to promote the reform of audit teaching, colleges and universities should change the mode of audit teaching, combine offline teaching with online teaching, promote the integration of audit teaching and accounting teaching, and establish informationbased audit training base according to the conditions, so as to cultivate audit talents with the characteristics of The Times.

\section{AUTHORS' CONTRIBUTIONS}

This paper is independently completed by Liyun Chen.

\section{REFERENCES}

[1] Liang Liwen, Exploration and Practice of Online and Offline Mixed Teaching Mode Taking Accounting and Auditing Practice of Higher Vocational Education as an Example, China Township Enterprises Accounting, 2021 (1)

[2] Feng Na, Sun Jianing, Pang Haiying, Research on the Teaching Reform of "The Flipped Classroom" of Auditing, China Township Enterprises Accounting, 2020 (11)

[3] Chen Lilan, Research on the Teaching Reform of Auditing under the New Audit Reporting Standards - Based on the Concept of Flipped Classroom, Journal of Inner Mongolia University of Finance and Economics, 2019 (17) 
[4] Wei Qianni, Construction of the Intelligent Teaching Platform for the Practice Courses of Auditing in Private Universities under the Background of "Internet Plus Education", Comparative Study of Cultural Innovation, 2020 (11)

[5] Wu Qinhong, Research on the Current situation and optimization design of Audit Informatization Experimental Teaching, China Management Informatization, 2015 (18)

[6] Liu Jie, Han Hongling, Chen Hanwen, Audit Reform in the Era of Big Data: Analysis Framework and Implementation Path, Financial Research, 2019 (5) 